\title{
Territorial Competitiveness in Central and Eastern Europe
}

\author{
Prof Janos Rechnitzer ${ }^{1} \&$ Tamas Toth ${ }^{1}$ \\ ${ }^{1}$ Szechenyi Istvan University, Gyor, Hungary \\ Correspondence: Tamas Toth, Szechenyi Istvan University, Gyor Egyetem ter 1, Hungary. Tel: 36-20-557-3023. \\ E-mail: tamas.toth@sze.hu
}

Received: April 5, 2014

Accepted: April 16, 2014

Online Published: April 18, 2014

doi:10.5430/jbar.v3n1p96

URL: http://dx.doi.org/10.5430/jbar.v3n1p96

\begin{abstract}
The aim of this study is to present a regional competitiveness model based on a general model of competitiveness that is able to rank the NUTS 2 regions of East and Central based on their respective incomes per capita. The major goal of this analysis is to numerically support the assumption that there are competitiveness gaps both between the capital city and countryside and the Northern and Southern regions of the countries. This is a fact, which strictly determines the regional development policies.
\end{abstract}

Keywords: Spatial structure, Regional policy, Competitiveness, CEE region

\section{Introduction}

The past few years have seen a dramatic increase in the number of Hungarian and international investigations and studies on East-Central Europe. From a geopolitical aspect this increase is warranted. This region is located between West and East. In an environment of ever changing high political focus this position has been and will continue to be validated in unique ways. Analyses view the "Central European Boomerang" connecting the cities Gdansk-Poznan-Wroclaw-Prague-Brno-Bratislava-Budapest as East-Central Europe's western developmental zone. The countries of the region display a development pattern in which the levels of eastern and western regions are markedly different. A general tendency is for regional resources to be concentrated in capital cities and their wider agglomerations, which are consistently prominent. Beyond capital cities only a few large urban areas or regional centers are able to demonstrate a fast development dynamic. This article analyzes the processes of spatial structure of the East-Central European region in detail, outlining current and anticipated spatial development directions.

\section{The Region under Examination}

What exactly is East-Central Europe? Attempts to define this region of Europe have given rise to several theories (Szücs \& Hanák, 1986), and thoughtful analyses attempting to record the characteristics of this group of countries have been written. Valuable analyses of the development of social and economic structures after the regime changes are available (Ehrlich, Révész \& Tamási, 1994). Some studies have tried to describe territorial characteristics (Horváth, 2000; Illés, 2002) or the system of municipal networks and the characteristics of their definitive centres (Csapó \& Balogh, 2012; Csomós, 2011; Enyedi, 2010; Tagai, 2010). Publications have appeared on the development of structural policies (Fábián, 2011), the territorial policies of specific countries, their tools (Mezei, 2006; Rechnitzer \& Smahó, 2011), the modelling and transformation of economic and industrial structures (Kuttor, 2012; Lux, 2009; Molnár, 2012) and the definition of regional competitiveness (Lengyel, 2012). The past few years have seen a dramatic increase in the number of Hungarian and international investigations and studies on East-Central Europe, indicating that this group of countries has become a focus for professional researchers.

A review of publications reveals that there are differences and divergences in drawing the borders of the region. One group of researchers focuses on the countries of the Visegrad Co-operation initiative established in 1991 (Czech Republic, Hungary, Poland, Slovakia), while many researchers add Austria and call the region Central Europe. Other analyses attach the eastern counties of Germany, or Bavaria, and also include western Balkan countries (Horváth \& Hajdú 2010) like Slovenia and Romania and thus speak of East-Central Europe.

We prefer this more encompassing approach, given that the countries all joined the European Union at about the same time, or are about to join (Croatia in 2013, while Serbia's accession date remains uncertain). From a Hungarian point of view this group of countries has a number of historical similarities, while in the 20th century the given countries and by extension the region formed millions of economic, trade and historical-cultural threads that 
entwined them. Furthermore, the countries of the region experienced similar political systems, and the collapse of these regimes occurred at roughly the same time throughout the region, giving rise to similarities in regime transformation.

Last but not least a unique geopolitical situation characterizes these countries. They are located between West and East and in an environment of ever changing high political focus this position has been and will continue to be validated in unique ways. As such, our study incorporates a bigger, and in our view more coherence set of countries, which is similar in terms of development and catalysts thereof. Thus, we see East-Central Europe as the Southern and Eastern states of Germany, Poland, the Czech Republic, Slovakia, Hungary, Slovenia and Romania. Within this group of countries - as in a European greater area - we attempt to describe a spatial structure and its changes.

\section{On Spatial Structure}

In his outstanding study (Szabó, 2009) and later habilitation (2012) Pál Szabó summarizes Hungarian interpretations of spatial structure (Szabó, 2012). He provides three approaches to the use of the term. In the first instance the elements (creation factors) and their spatial arrangement are viewed as the foundation of the definition, while a second interpretive approach categorizes based on statements emphasizing spatial component elements. Finally, the third approach is found in investigations where the relation of spatial elements to one another, i.e., the divergences in structures and analysis of their spatial distribution are focal points.

To make possible comparison, i.e., the illustration of divergence in spatial development, we will connect the other classification by the author, which can be created in geographical or regionalist (territorial development) aspects. Szabó considers the connection between regions and spatial structure, or the description of geographical spaces cut up by network elements (transportation, settlement networks) to be geographical approaches. The regional approach covers those who draw borders based on the quantitative and qualitative differentiation among spatial structure elements and then based on such define given spatial development directions. Analyses focusing on one country can be based on administrative units (settlements, micro-regions, counties, planning-statistical regions), which are then typified and characterized as spatial formations. These are then differentiated from other spatial formations according to common characteristics as specified in the given analyses. Differentiation can also mean comparison to an assumed or real level of development, which can form the foundation for statements on spatial structure(s).

It is our position that the regional approach is directed at making it possible to define spatial developmental directions. We designate those structures upon which it is possible to describe the developmental characteristics of a part of a country, a country, a group of countries or even a continent. Given the criterion for examination we can tailor directions for developmental interventions according to spatial distribution and differentiation in the spatial structure. All this is done with an eye to defining attainable (policy) goals and then assigning tools and institutions for execution.

Spatial structure is thus the defining of territorial units based on groups or combinations of distinguishable development paths independent of a country or group of countries' spatial position, and further based on groups of primarily economic, social, settlement-network factors (Rechnitzer \& Smahó, 2012). Its characteristics, e.g., differentiated structural, organizational units, form unique combinations that can be characterized and evaluated according to given criteria. These characteristics define the economic, social and settlement-network factors in one or several time periods. The units of spatial structure thus can be described as the state of a developmental path, evaluated according to expectations (e.g., development, separation), and defined in order to achieve changes according to territorial policy goals (desired future development directions, transformation of situations and states, means and modes of intervention).

Spatial structure units are the concentrated appearance of similar or seemingly similar (interconnected), determining economic, social and settlement-network factors. Space has several layers and fields which pile on top of one another and which can strengthen or weaken one another (Rechnitzer \& Smahó, 2011). The specificities and differences of spatial fields depend on the geographical characteristics of various territories, their economic, social and political evaluation, or their level of support. In this way their role in the transformation of spatial structure can vary. One of the goals of spatial policy is to influence and contribute to the transformation of these spatial fields.

The various fields are layered upon one another in space, but their effect and strength in given spatial points (settlements) can vary. Some intensify and become concentrated, while the presence of others wanes. Meanwhile the fields affect, build, destroy and weaken one another. The relations and destinations between fields change over time. Within a given span of time some gain in value, others become dormant or lose their previous significance and role. In the next span of time they can reappear in a new light or correlation, establish a relation with a further field and 
affecting those create new synergies. Change in the entirety of the spatial structure follows transformation of the fields or the appearance of new points of view and interrelations in the valuation of fields.

The goal of analyzing spatial structure is thus to determine the composition of the examined territorial unit - be it a country or group/association of countries that displays common characteristics as regards units and unifying criteria in space - in terms of definable composite elements, with an eye to the future direction of their change and development. A further goal is the orientation of development and the review of what possible interventions are necessary to change or modify the described states. Such spatial structure analyses can encompass the registration of current states, the description of a desired future state, or the establishment/prediction of a developmental level. These analyses can be viewed as tools of territorial policy used to define the direction of interventions. It follows that spatial structure analysis can be viewed as an analytical tool of horizontal developmental policy. Given the above, spatial structure types can be defined as developmental levels, or differentiable spatial characteristics. We can move from states seen as developed toward undeveloped or - in terms of given conditions - designate them as lagging or peripheral. The degrees, or the placement of demarked territorial units on a ladder of development, can change according to analyses and in light of territorial policy goals.

Finally, a definitive question is that of the mode or methodological foundation for designating spatial structure units or development types. Numerous analytical methods for qualifying territorial levels, registering their states or comparing them to one another are known or are being developed. To simplify, there are two paths we can take. The first path is classification according to indicators of development. In such cases we utilize one or more well known indicators (these are usually indicators of territorial economic potential, e.g., GDP per person), separate the territorial units, and then using our further gathered knowledge refine and increase the precision of our picture. The other solution is to collect various economic, social and municipal indicators characterizing territorial units - essentially the field characteristics - and analyze them using complex evaluation methods (e.g., multivariable analyses, projection methods, simulation techniques, etc.).

Both approaches can be used successfully, while the combination of the two can also be a solution. We should not forget that the goal of spatial structure analysis is the orientation of development and the establishment of its possible directions. Hence, territorial analysis requires experience in synthesizing, creative problem solving and knowledge of the given territorial units. The method of presenting results is map diagrams, but this only helps envision observations in spatial terms. These - as spatial structure units - must be described with great precision and based on development-supporting relations.

\section{East-Central Europe in European Spatial Structure}

Spatial structure models of Europe appeared in the eighties and nineties of the previous centuries, with the goal of illustrating the developmental direction of European space. Illustrations and grandiose spatial demarcations were based on the classic principles of the center-periphery model. Central spaces - whose nodes were the large centers of Western Europe - housed concentrated economic resources as well as all institutions of political decision-making, and this well-defined space was the starting point of economic renewal and the concentration of innovation. This is how the Blue Banana came to be, as Europe's economic - and historically interpretable - belt, which contained Western Europe's dominant centers and their spheres of influence (Brunet, 1989). Rethinking of the models results in the expansion of this belt through the inclusion of agglomerations and new centers. The forming developmental zone now stretches from London and Paris through the Ruhr area to Milan, encompassing Europe's definitive centers and their areas of influence (Kunzmann, 1992).

The outlining of developmental zones continued in the 1990s. The South European developmental zone appeared, encompassing the centers of Barcelona, Lyon, Marseille, Genoa, Milan, Venice and Rome, along with their agglomeration zones. This developmental axis - having unique functions (service orientation, tourist, strengthening local economies, new type production systems and regional connections) - was named the North of the South, Europe's Sunbelt or the Second Banana (Lever, 1995).

In addition to these was the outline of Europe's high-tech ring, which began in Glasgow, went through Barcelona and Milan to Vienna, broke in Central Europe, and then closed the circle from Malmo to the original starting point. This is where Vienna first appears, then as Europe's last stop, beyond which peripheral areas like East-Central Europe which are unknown and undocumented - are to be found.

At the beginning of the 1990s regional processes clearly showed that the economic integration of East-Central European countries would inevitably give rise to a regional integration form (Enyedi, 1996). The established Visegrad Co-operation initiative, the countries of which had economic and institutional principles that made 
economic integration possible, could have initiated a concurrent territorial integration process not just with neighboring countries in what was then the European Community, but with eastern, post-socialist neighbor countries as well. Some signs of such an integration process were recognizable in the emerging macro-regional structure of East-Central European countries (Gorzelak, 1996; Rechnitzer, 1998), which displayed several particularities and at the same time certain directions of development.

In the mechanism of macro-regions it is urban regions that embody connections. In Hungary this means the Budapest agglomeration; the agglomerations of Prague and Brno in the Czech Republic; Warsaw, Poznań, Wroclaw, Gdansk and Krakow in Poland; and the Bratislava area and the Kosice region in Slovakia. The west-east developmental slope in these countries was already present at the time, although approaching the eastern borders this continuity was broken and we experience a sharp drop to another level of development that is markedly unfavorable compared to the previous one. Therefore the studies viewed the countries of the East-Central Europe region as the border zone of the west, which could lay a foundation for macro-regional and cross-border co-operation, whereas the eastern regions were the true periphery, with little chance for catching up.

The western developmental zone of East-Central Europe, which encompasses the major cities of Gdansk, Poznan, Wroclaw, Prague, Brno, Bratislava, Vienna and Budapest, was seen in analyses as the "Central European Banana" (or boomerang). This zone has a high concentration of capital cities and significant industrial and administrative centers. Their organizations are directly connected to the Austrian and German economies. Major and mid-sized investors have settled in these regions. Furthermore, these centers were able to absorb services and shopping tourism from the west in the middle of the 1990s. It is another unique aspect that in this zone the relatively developed areas of East-Central Europe - which largely had industrial potential and advantageous infrastructure - merged with the relatively underdeveloped Austrian and German regions (which showed significant transformations). As a result, a natural situation of competition arose among the areas. This not only covered Austrian-German relations, but also affected intraregional relations in the given countries. By this we mean that as a result of the inflow of western capital into these western-located or capital city-based regions the transformation of the economy was quicker - i.e., more successful - and hence the west-east or capital city-countryside division increased instead of diminishing.

The Central European banana (or boomerang) can launch two potential development zones or expansions. One of the zones begins in Prague and includes the large industrial cities of former East Germany (Berlin, Leipzig), connecting to Berlin, and then turns to Poznan and back to the Czech capital. The Berlin-Warsaw axis is forming at a spectacular rate, not only as a new transportation and communications corridor (Pan-European Transport Corridor No. 2) in the near future - opening toward Minsk and Moscow - but as a new innovation axis as well. This may result in a shift in the center of gravity in the spatial structure of East-Central Europe, as much of the transportation of goods can be "lured" here and new economic directions can be established that devalue and diminish earlier spatial connections. The entire spatial structure could be transformed as a result.

Another potential expansion of the Central European banana (or boomerang) is along a north-south axis that can connect the coast of the Adriatic Sea with the North Sea. This possible expansion can emphasize the Berlin-Warsaw axis, and can also activate Slovenia, Croatia and the eastern and southern counties of Austria. Due to the unique aspects of spatial structure it can be assumed that the future fusion of East-Central Europe's northern and southeastern development areas will take place along the Prague-Brno-Vienna-Bratislava-Györ-Budapest axis. An economic and spatial structure turntable can form here (East-Central European mushroom) which can fuse East-Central Europe's future renewal zones with Eastern Europe (mainly eastern Slovakia and the Ukraine) and the Balkans (largely Romania, Serbia and Bulgaria), transferring capital, knowledge and innovation to the latter two areas and their centres.

Beyond current and potential future development zones, transitional areas with various characteristics were also present in East-Central Europe in the 1990s. Some of these were traditional industrial districts, transformational agricultural districts, mountainous zones with active tourism or large cities or peripheries hoping to utilize cross-border co-operation. One could draw an "eastern wall" that broke the developmental slope and encompassed the peripheral border areas - those touching Belorussia and the Ukraine - of the eastern part of the group of countries. Characteristically most of these areas were provincial, based on agriculture, contained a village and small-city settlement network, were unfavorably developed, and had poorer infrastructure than the national average. In other provincial cities the inner resources for renewal were lacking, there was scant interest on the part of foreign capital, and tensions in employment and society were sharp. Beyond the numerous disadvantages of being on the periphery, the fact that the post-Soviet areas bordered so-called "western" regions made it possible for them to activate various elements of resources and to establish new areas for relations. The dismantling of the "eastern wall", however, was 
obstructed by dilapidated and narrowly cross-sectioned transportation (and border crossing) infrastructure, by the slow development of post-Soviet state institutions, by the increased defense of the eastern borders of the European Union, by the flowering of the black market, and by markedly poor public safety.

\section{Competitiveness}

A basic change to the 21 st century economic theory was that due to the global capital flow and commercial activities models on economic activities' spatial concentration and the reconsideration of the related competitiveness theories came to the fore. By now, territorial competition has been already strengthened, which phenomenon used to be explained by growing returns to scale and the exploitation of agglomeration benefits by the literature of regional economics.

Business theories have two distinctive theories to explain competition. Keynes and the followers of the neoliberal theory - based on the theory of comparative advantages- say that market automatically mitigates the territorial differences of income inequality, thus everyone is able to participate in the international economy and commerce by exploiting his own comparative advantages (Krugman, 1994).

Based on Krugman's well known theory we cannot speak of competition here, since both competitive edges and disadvantages disappear in a win to win situation. Besides, Krugman sharply criticizes the theory from the viewpoint of territoriality, since while a company can liquidate itself in case of a potential insolvency, a territorial unit cannot do so, thus, micro level and territorial competitiveness are handled separately in his theories (Krugman, 1998; 1999).

According to the followers of competitive theories market automatisms and the "invisible hand" are not able to mitigate territorial inequalities, in order to reach equalization accurate intervention is needed based on the adequate resources (Lengyel \& Rechnitzer, 2004). In this theory, the distribution of income is the outcome of a constant sum game, in the given situation the group of winners and losers can be undoubtedly identified. The regional policy of the European Union is based on the competitive theories, which, keeping territoriality in mind, ensures adequate transfers in order to facilitate the close up of underdeveloped regions (EC, 2008).

In Rapkin's view competitiveness is a measure, which shows whether a national economy under perfect competition is able to sell goods and services on the global market (as well). The theories of Porter define competitiveness rather on company level and they set productivity in the focus of the analysis. There are two main branches of corporate competitiveness based on Porter's work, where supply and demand are divided. The supply side (production) theory is proceeding from the fact that lower specific factor costs mean an advantage in the competition. Not only the comparative cost advantage is important, but how the company is able to benefit from this. According to the followers of the demand side (market) theory competitiveness can be depicted as a change in market share.

Based on the above classification the OECD defined the below definitions regarding the competitiveness of nations:

- Supply side: reaching a relative high factor income and maintaining a high level of employment under the circumstances of market competition

- Demand side: increasing the market share on domestic and international markets.

The basic indicator used for modelling the supply side is the labor cost unit, which is formulated as follows: whole labor cost of a branch or a national economy divided by the economic value added (EVA). The demand side can be characterized by the proportion of export covered with import (OECD, 2011)

According to Lengyel there are three types of economic competition: labor market competition, corporate competition and competition among territorial units. Territorial competitiveness is modeling competition among regions, where the single entities compete for capital and information on the global market, which factors form the base of competitive advantages in order to reach a higher level of welfare. (Lengyel, 2003).

\section{Regional competitiveness}

Regional competitiveness can be also approached by aggregating the competitiveness of the region's companies and measuring the general competitiveness of the region. The main problem of the first view is that it can hardly handle the problem of premises beyond the region, therefore in Lengyel's opinion regional competitiveness can only be characterized by a complex group of indicators related to the given territory. Concerning the indicators measuring regional competitiveness there is no unambiguous position in the literature, the various groups of indices differ very much considering both their structure and complexity (Bristow, 2010).

In the Hungarian literature the most popular complex competitiveness model is the "Pyramid model", which describes the endogenous growth potential by using different hard and soft exogenous variables. On the top of the 
pyramid stands the level of welfare in the given region, this is directly determined by the regional income level. The income is determined by the level of labor productivity and employment, which factors are determined by R\&D, infrastructure, FDI, the SME sector and the institutional social capital. The pillars of the model are those hardly measurable soft competitiveness factors, which determine regional competitiveness in the long run (Lengyel, 2004).

Among the simpler modeling tools of regional competitiveness we need to mention the measurement of regional GDP and NDI. Regional GDP is a part of the gross domestic product produced in the given region, i.e. the primary revenues created within a year (e.g. wages, interests, dividends, rent of land, corporate profit and amortization) realized by the region based companies and the individuals living there (Szabó, 1998). Regional NDI is the income on the disposal of the region's population: the sum of primary income realized by the permanent residents of the region that they might earn for their activities carried out in other regions, or that might be expatriated by the ones living in other regions (e.g. abroad), and it also might be corrected by the interregional income transfers (secondary income flows) (Lengyel, 2000).

The EU uses the indicator of regional GDP when measuring the incomes created on NUTS2 level. This can be classified into three main components:

$G D P /$ population $=G D P /$ persons in employment $*$ persons in employment/ persons in active age*

*persons in active age/population

The first component, the output per capita is approximately the same as the regional labor productivity, i.e. the output per hour worked.

The second component is the employment rate, which is the proportion of persons in employment among the population of working age. The main problem of the indicator is that commuting distorts the results; therefore minor corrections are necessary in case of regional analyses.

The third component measures the proportion of working age population among the total population. This component can only be improved to a lesser extent with the application of regional policy tools, therefore - in the short run- it needs to be considered constant.

In the last part of our paper we are going to present the competitiveness of East-Central Europe's NUTS 2 regions in terms of the above three main components of regional GDP.

\section{Components of competitiveness}

As the first step in our analysis we studied the regional income distribution and its development as defined by the three main components (presented in the theoretical part of this paper) in the NUTS 2 units of eight East and Central European counties (Poland, Czech Republic, Hungary, Slovakia, Slovenia, Croatia, Romania, Bulgaria) (table 1). The deviation data show that regional incomes deviate on the average by $59 \%$ from the average, which phenomenon is mainly due to the inner deviation caused by labor productivity, while in case of employment rate and the proportion of working age population an average deviation under $10 \%$ can be perceived. 
Table 1. Main components of competitiveness, indexes (source: EuroStat, 2014)

\begin{tabular}{|c|c|c|c|c|c|}
\hline & & GDP/DEM & GDP/EMP & EMP/ACT & $\mathrm{ACT} / \mathrm{DEM}$ \\
\hline Bulgaria & BG TOTAL & 4,77 & 11,98 & $89,69 \%$ & $44,37 \%$ \\
\hline Severozapaden & BG1 & 2,87 & 8,34 & $88,93 \%$ & $38,65 \%$ \\
\hline Severen tsentralen & BG2 & 3,12 & 8,58 & $88,39 \%$ & $41,06 \%$ \\
\hline Severoiztochen & BG3 & 3,88 & 10,04 & $85,38 \%$ & $45,24 \%$ \\
\hline Yugoiztochen & BG4 & 3,88 & 10,25 & $89,28 \%$ & $42,42 \%$ \\
\hline Yugozapaden & BG5 & 8,22 & 17,84 & $93,20 \%$ & $49,46 \%$ \\
\hline Yuzhen tsentralen & BG6 & 3,32 & 8,61 & $88,51 \%$ & $43,57 \%$ \\
\hline Croatia & CR TOTAL & 14,30 & 31,24 & $92,63 \%$ & $49,42 \%$ \\
\hline Jadranska Hrvatska & CR1 & 30,93 & 60,52 & $96,17 \%$ & $53,15 \%$ \\
\hline Kontinentalna Hrvatska & CR2 & 12,66 & 26,60 & $94,70 \%$ & $50,26 \%$ \\
\hline Czech Republic & CZ TOTAL & 12,38 & 26,48 & $94,35 \%$ & $49,57 \%$ \\
\hline Praha & CZ1 & 11,23 & 25,71 & $88,84 \%$ & $49,19 \%$ \\
\hline Strední Cechy & $\mathrm{CZ2}$ & 11,69 & 25,96 & $92,89 \%$ & $48,47 \%$ \\
\hline Jihozápad & $\mathrm{CZ3}$ & 12,82 & 28,22 & $92,42 \%$ & $49,15 \%$ \\
\hline Severozápad & $\mathrm{CZ4}$ & 11,37 & 26,15 & $91,15 \%$ & $47,72 \%$ \\
\hline Severovýchod & $\mathrm{CZ5}$ & 12,01 & 27,82 & $89,80 \%$ & $48,09 \%$ \\
\hline Jihovýchod & CZ6 & 10,14 & 30,07 & $87,89 \%$ & $38,35 \%$ \\
\hline Strední Morava & $\mathrm{CZ7}$ & 9,96 & 31,91 & $88,48 \%$ & $35,28 \%$ \\
\hline Moravskoslezsko & CZ8 & 10,22 & 29,26 & $87,63 \%$ & $39,87 \%$ \\
\hline Hungary & HU TOTAL & 9,64 & 25,76 & $88,77 \%$ & $42,19 \%$ \\
\hline Közép-Magyarország & HU1 & 15,93 & 38,71 & $90,98 \%$ & $45,23 \%$ \\
\hline Közép-Dunántúl & HU2 & 8,41 & 21,46 & $89,69 \%$ & $43,72 \%$ \\
\hline Nyugat-Dunántúl & HU3 & 9,65 & 23,90 & $90,80 \%$ & $44,49 \%$ \\
\hline Dél-Dunántúl & HU4 & 6,56 & 18,35 & $87,85 \%$ & $40,72 \%$ \\
\hline Észak-Magyarország & HU5 & 5,86 & 18,17 & $83,87 \%$ & $38,46 \%$ \\
\hline Észak-Alföld & HU6 & 6,11 & 18,45 & $85,40 \%$ & $38,81 \%$ \\
\hline Dél-Alföld & HU7 & 6,27 & 17,28 & $89,32 \%$ & $40,63 \%$ \\
\hline Poland & PL TOTAL & 9,29 & 22,56 & $90,27 \%$ & $45,62 \%$ \\
\hline Lódzkie & PL1 & 8,55 & 17,47 & $90,67 \%$ & $53,96 \%$ \\
\hline Mazowieckie & PL2 & 15,14 & 33,43 & $92,48 \%$ & $48,97 \%$ \\
\hline Malopolskie & PL3 & 7,90 & 20,60 & $90,70 \%$ & $42,28 \%$ \\
\hline Slaskie & PL4 & 9,93 & 24,99 & $90,85 \%$ & $43,72 \%$ \\
\hline Lubelskie & PL5 & 6,27 & 13,65 & $89,93 \%$ & $51,10 \%$ \\
\hline Podkarpackie & PL6 & 6,25 & 15,94 & $87,91 \%$ & $44,63 \%$ \\
\hline Swietokrzyskie & PL7 & 7,03 & 14,55 & $87,81 \%$ & $55,03 \%$ \\
\hline Podlaskie & PL8 & 6,75 & 16,71 & $89,65 \%$ & $45,06 \%$ \\
\hline Wielkopolskie & PL9 & 9,69 & 24,12 & $91,15 \%$ & $44,07 \%$ \\
\hline Zachodniopomorskie & PL10 & 8,08 & 23,75 & $87,56 \%$ & $38,84 \%$ \\
\hline Lubuskie & PL11 & 7,85 & 18,14 & $89,40 \%$ & $48,40 \%$ \\
\hline Dolnoslaskie & PL12 & 10,45 & 25,98 & $88,67 \%$ & $45,38 \%$ \\
\hline Opolskie & PL13 & 7,38 & 20,65 & $90,27 \%$ & $39,57 \%$ \\
\hline Kujawsko-Pomorskie & PL14 & 7,79 & 20,25 & $89,36 \%$ & $43,05 \%$ \\
\hline Warminsko-Mazurskie & PL15 & 6,82 & 17,28 & $90,30 \%$ & $43,70 \%$ \\
\hline Pomorskie & PL16 & 8,93 & 24,15 & $90,68 \%$ & $40,79 \%$ \\
\hline Romania & RO TOTAL & 5,79 & 14,09 & $92,41 \%$ & $44,48 \%$ \\
\hline Nord-Vest & RO1 & 5,18 & 12,78 & $92,98 \%$ & $43,56 \%$ \\
\hline Centru & $\mathrm{RO} 2$ & 5,56 & 14,79 & $89,35 \%$ & $42,05 \%$ \\
\hline Nord-Est & $\mathrm{RO} 3$ & 3,56 & 8,44 & $93,75 \%$ & $45,03 \%$ \\
\hline Sud-Est & RO4 & 4,77 & 12,20 & $90,89 \%$ & $42,99 \%$ \\
\hline Sud - Muntenia & RO5 & 4,81 & 11,71 & $91,21 \%$ & $45,03 \%$ \\
\hline Bucuresti - Ilfov & RO6 & 13,77 & 29,71 & $95,45 \%$ & $48,57 \%$ \\
\hline Sud-Vest Oltenia & RO7 & 4,44 & 10,79 & $91,78 \%$ & $44,87 \%$ \\
\hline Vest & RO8 & 6,56 & 15,91 & $93,86 \%$ & $43,92 \%$ \\
\hline Slovenia & SI TOTAL & 17,39 & 37,82 & $92,59 \%$ & $49,68 \%$ \\
\hline Vzhodna Slovenija & SI1 & 14,36 & 31,82 & $91,91 \%$ & $49,10 \%$ \\
\hline Zahodna Slovenija & SI2 & 20,82 & 44,32 & $93,33 \%$ & $50,33 \%$ \\
\hline Slovakia & SK TOTAL & 12,14 & 28,55 & $85,58 \%$ & $49,70 \%$ \\
\hline Bratislavský kraj & SK1 & 29,38 & 57,98 & $93,76 \%$ & $54,05 \%$ \\
\hline Západné Slovensko & SK2 & 11,36 & 25,41 & $87,31 \%$ & $51,21 \%$ \\
\hline Stredné Slovensko & SK3 & 9,89 & 24,30 & $83,46 \%$ & $48,75 \%$ \\
\hline Východné Slovensko & SK4 & 8,21 & 21,42 & $81,51 \%$ & $47,01 \%$ \\
\hline Central and Eastern Europe & CEE & 9,12 & 22,23 & $90,49 \%$ & $45,32 \%$ \\
\hline
\end{tabular}


As shown in table 2, in every country in the region it is the capital city's NUTS 2 entity, which shows the highest level of production per capita, besides, considering both labor productivity and employment rate these regions have the leading role in the single national economies. Croatia is an exception to this rule, where - although the Zagreb centered continental region has a higher income level than the costal region - it is lagging behind considering both labor productivity and employment rate.

Table 2. Main components of competitiveness, \% of group average (source: EuroStat, 2014)

\begin{tabular}{|c|c|c|c|c|c|}
\hline & & GDP/DEM & GDP/EMP & EMP/ACT & ACT/DEM \\
\hline Bulgaria & BG TOTAL & $52 \%$ & $54 \%$ & $99 \%$ & $98 \%$ \\
\hline Severozapaden & BG1 & $31 \%$ & $37 \%$ & $98 \%$ & $85 \%$ \\
\hline Severen tsentralen & BG2 & $34 \%$ & $39 \%$ & $98 \%$ & $91 \%$ \\
\hline Severoiztochen & BG3 & $43 \%$ & $45 \%$ & $94 \%$ & $100 \%$ \\
\hline Yugoiztochen & BG4 & $43 \%$ & $46 \%$ & $99 \%$ & $94 \%$ \\
\hline Yugozapaden & BG5 & $90 \%$ & $80 \%$ & $103 \%$ & $109 \%$ \\
\hline Yuzhen tsentralen & BG6 & $36 \%$ & $39 \%$ & $98 \%$ & $96 \%$ \\
\hline Croatia & CR TOTAL & $111 \%$ & $135 \%$ & $97 \%$ & $85 \%$ \\
\hline Jadranska Hrvatska & CR1 & $109 \%$ & $144 \%$ & $98 \%$ & $78 \%$ \\
\hline Kontinentalna Hrvatska & CR2 & $112 \%$ & $132 \%$ & $97 \%$ & $88 \%$ \\
\hline Czech Republic & CZ TOTAL & $157 \%$ & $141 \%$ & $102 \%$ & $109 \%$ \\
\hline Praha & $\mathrm{CZ1}$ & $339 \%$ & $272 \%$ & $106 \%$ & $117 \%$ \\
\hline Strední Cechy & CZ2 & $139 \%$ & $120 \%$ & $105 \%$ & $111 \%$ \\
\hline Jihozápad & $\mathrm{CZ3}$ & $136 \%$ & $119 \%$ & $104 \%$ & $109 \%$ \\
\hline Severozápad & $\mathrm{CZ4}$ & $123 \%$ & $116 \%$ & $98 \%$ & $109 \%$ \\
\hline Severovýchod & $\mathrm{CZ5}$ & $128 \%$ & $117 \%$ & $103 \%$ & $107 \%$ \\
\hline Jihovýchod & CZ6 & $141 \%$ & $127 \%$ & $102 \%$ & $108 \%$ \\
\hline Strední Morava & $\mathrm{CZ7}$ & $125 \%$ & $118 \%$ & $101 \%$ & $105 \%$ \\
\hline Moravskoslezsko & $\mathrm{CZ8}$ & $132 \%$ & $125 \%$ & $99 \%$ & $106 \%$ \\
\hline Hungary & HU TOTAL & $106 \%$ & $116 \%$ & $98 \%$ & $93 \%$ \\
\hline Közép-Magyarország & HU1 & $175 \%$ & $174 \%$ & $101 \%$ & $100 \%$ \\
\hline Közép-Dunántúl & HU2 & $92 \%$ & $97 \%$ & $99 \%$ & $96 \%$ \\
\hline Nyugat-Dunántúl & HU3 & $106 \%$ & $107 \%$ & $100 \%$ & $98 \%$ \\
\hline Dél-Dunántúl & HU4 & $72 \%$ & $83 \%$ & $97 \%$ & $90 \%$ \\
\hline Észak-Magyarország & HU5 & $64 \%$ & $82 \%$ & $93 \%$ & $85 \%$ \\
\hline Észak-Alföld & HU6 & $67 \%$ & $83 \%$ & $94 \%$ & $86 \%$ \\
\hline Dél-Alföld & HU7 & $69 \%$ & $78 \%$ & $99 \%$ & $90 \%$ \\
\hline Poland & PL TOTAL & $102 \%$ & $101 \%$ & $100 \%$ & $101 \%$ \\
\hline Lódzkie & PL1 & $94 \%$ & $79 \%$ & $100 \%$ & $119 \%$ \\
\hline Mazowieckie & PL2 & $166 \%$ & $150 \%$ & $102 \%$ & $108 \%$ \\
\hline Malopolskie & PL3 & $87 \%$ & $93 \%$ & $100 \%$ & $93 \%$ \\
\hline Slaskie & PL4 & $109 \%$ & $112 \%$ & $100 \%$ & $96 \%$ \\
\hline Lubelskie & PL5 & $69 \%$ & $61 \%$ & $99 \%$ & $113 \%$ \\
\hline Podkarpackie & PL6 & $69 \%$ & $72 \%$ & $97 \%$ & $98 \%$ \\
\hline Swietokrzyskie & PL7 & $77 \%$ & $65 \%$ & $97 \%$ & $121 \%$ \\
\hline Podlaskie & PL8 & $74 \%$ & $75 \%$ & $99 \%$ & $99 \%$ \\
\hline Wielkopolskie & PL9 & $106 \%$ & $108 \%$ & $101 \%$ & $97 \%$ \\
\hline Zachodniopomorskie & PL10 & $89 \%$ & $107 \%$ & $97 \%$ & $86 \%$ \\
\hline Lubuskie & PL11 & $86 \%$ & $82 \%$ & $99 \%$ & $107 \%$ \\
\hline Dolnoslaskie & PL12 & $115 \%$ & $117 \%$ & $98 \%$ & $100 \%$ \\
\hline Opolskie & PL13 & $81 \%$ & $93 \%$ & $100 \%$ & $87 \%$ \\
\hline Kujawsko-Pomorskie & PL14 & $85 \%$ & $91 \%$ & $99 \%$ & $95 \%$ \\
\hline Warminsko-Mazurskie & PL15 & $75 \%$ & $78 \%$ & $100 \%$ & $96 \%$ \\
\hline Pomorskie & PL16 & $98 \%$ & $109 \%$ & $100 \%$ & $90 \%$ \\
\hline Romania & RO TOTAL & $64 \%$ & $63 \%$ & $102 \%$ & $98 \%$ \\
\hline Nord-Vest & RO1 & $57 \%$ & $57 \%$ & $103 \%$ & $96 \%$ \\
\hline Centru & $\mathrm{RO} 2$ & $61 \%$ & $67 \%$ & $99 \%$ & $93 \%$ \\
\hline Nord-Est & RO3 & $39 \%$ & $38 \%$ & $104 \%$ & $99 \%$ \\
\hline Sud-Est & RO4 & $52 \%$ & $55 \%$ & $100 \%$ & $95 \%$ \\
\hline Sud - Muntenia & RO5 & $53 \%$ & $53 \%$ & $101 \%$ & $99 \%$ \\
\hline Bucuresti - Ilfov & RO6 & $151 \%$ & $134 \%$ & $105 \%$ & $107 \%$ \\
\hline Sud-Vest Oltenia & RO7 & $49 \%$ & $49 \%$ & $101 \%$ & $99 \%$ \\
\hline Vest & RO8 & $72 \%$ & $72 \%$ & $104 \%$ & $97 \%$ \\
\hline Slovenia & SI TOTAL & $191 \%$ & $170 \%$ & $102 \%$ & $110 \%$ \\
\hline Vzhodna Slovenija & SI1 & $157 \%$ & $143 \%$ & $102 \%$ & $108 \%$ \\
\hline Zahodna Slovenija & SI2 & $228 \%$ & $199 \%$ & $103 \%$ & $111 \%$ \\
\hline Slovakia & SK TOTAL & $133 \%$ & $128 \%$ & $95 \%$ & $110 \%$ \\
\hline Bratislavský kraj & SK1 & $322 \%$ & $261 \%$ & $104 \%$ & $119 \%$ \\
\hline Západné Slovensko & SK2 & $125 \%$ & $114 \%$ & $96 \%$ & $113 \%$ \\
\hline Stredné Slovensko & SK3 & $108 \%$ & $109 \%$ & $92 \%$ & $108 \%$ \\
\hline Východné Slovensko & SK4 & $90 \%$ & $96 \%$ & $90 \%$ & $104 \%$ \\
\hline Central and Eastern Europe & CEE & $100 \%$ & $100 \%$ & $100 \%$ & $100 \%$ \\
\hline
\end{tabular}


Table 3 represents the 5 most developed and 5 most underdeveloped regions, where- in line with the preconceptionthe V4 and Slovenian capital city regions belong to the first group, and the Romanian and Bulgarian regions to the second.

Table 3. The 5 most developed and 5 most underdeveloped region (source: EuroStat, 2014)

\begin{tabular}{cccccc}
\hline & & GDP/DEM & GDP/EMP & EMP/ACT & ACT/DEM \\
\hline Praha & CZ1 & 3,39 & 2,72 & 1,06 & 1,17 \\
Bratislavský kraj & SK1 & 3,22 & 2,61 & 1,04 & 1,19 \\
Zahodna Slovenija & SI2 & 2,28 & 1,99 & 1,03 & 1,11 \\
Közép-Magyarország & HU1 & 1,75 & 1,74 & 1,01 & 1,00 \\
Mazowieckie & PL2 & 1,66 & 1,50 & 1,02 & 1,08 \\
Nord-Vest & RO1 & 0,57 & 0,57 & 1,03 & 0,96 \\
Sud - Muntenia & RO5 & 0,53 & 0,53 & 1,01 & 0,99 \\
Sud-Est & RO4 & 0,52 & 0,55 & 1,00 & 0,95 \\
Sud-Vest Oltenia & RO7 & 0,49 & 0,49 & 1,01 & 0,99 \\
Yugoiztochen & BG4 & 0,43 & 0,46 & 0,99 & 0,94 \\
\hline
\end{tabular}

It can be unambiguously ascertained from the collected data that beyond the capital city-countryside gap another North to South gap can also be identified, since the Northern regions' economic activities surpass the regions in the South.

Figure 1 demonstrates the two-dimensional relationship between employment rate and labor productivity as a \% of group average (10 most and 10 underdeveloped region). This shows on the basis of which competitiveness component are the single NUTS 2 regions in the fore and lagging behind.

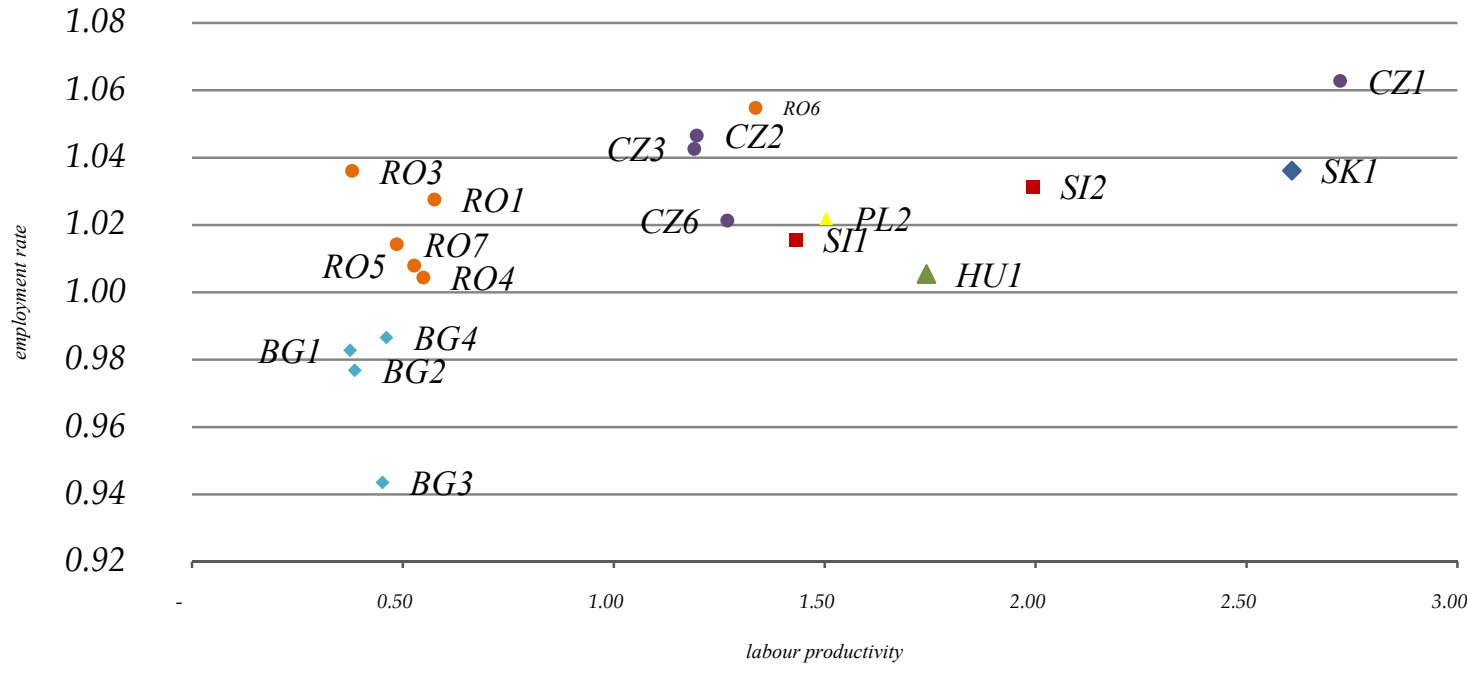

Figure 1. Relationship between labor productivity and employment rate (source: EuroStat, 2014)

The figure shows clearly that regional competitive advantages follow to the less extent from the employment rate and to the great extent from labor productivity. Almost every studied nation's capital city region has an above-average employment rate, however, the outstanding competitive advantage of the Prague and Bratislava regions are due to the productivity advantage. In case of Slovakia it is unambiguous that while the mentioned capital city region has an outstanding performance in the field of employment and labor productivity, the three other regions are much under the average in the first field and they show average values considering the second field.

In case of Romania, Bulgaria and Hungary it can be concluded that the regions are closer to each other, the single NUTS2 regions show relatively low deviation, only the capital cities stand out showing a deviation of $10-15 \%$. 


\section{Conclusion}

In our applied research we studied the values of Eastern and Central Europe's NUTS 2 statistical regions by the analysis of regional income's main components. The demonstrated analysis is providing exact data to support our presumption that income inequalities can be identified on the one hand in a capital city-countryside context, on the other hand in the gap between North and South. Although the deviation of employment rate and the proportion of working age population are relatively low, considering labor productivity the single entities differ from the average by average $47 \%$. We can conclude that regional income inequalities are mainly due to the labor used to produce a unit of output, while the employment rate and the proportion of active population do not explain this competitive advantage.

We can observe a development level split between western and eastern regions within the countries in question. Generally the capital cities and wider agglomeration regions have high concentration of resources and stand out in terms of their country's income generation and human potential. Beyond the capital cities only some large cities and regional centers are able to produce faster dynamic, largely those in which progressive branches capable of producing for the world market (e.g., vehicular, electronics industries) have undergone renewal, or where such branches recently took root, and where transportation processes are multifaceted. Among provincial regions built around smaller centers only those able to utilize or transform tourism advantages or unique agricultural cultures have seen convergence beginning. These regions can successfully participate in integration processes. We can further observe the gathering momentum of border-area relations and manifestations of forms thereof [e.g., macro-regional development strategies (Danube Strategy), construction of organizational systems (Euroregions), creation of new institutional frameworks (EGTC)] and the spread of spheres of influence and the attraction of large cities located near national borders to cross-border areas. This trend is getting more and more pronounced. The region as a whole is deeply divided. It is clear that the spatial structure manifestations of the processes mentioned above affect specific countries in different ways. There are some where territorial development is more even, while others have long-term and divisive structures having been developed. Competition between the countries and regions of East-Central Europe is increasingly visible and is actually further fuelled by the drawn out economic crisis and its effects, along with the diverging reactions to it.

\section{References}

Bristow, G. (2010). Critical reflections on regional competitiveness: theory, policy and practice. Routledge, Abingdon.

Brunet, R. (1989). Les villes Europas. Reclut/Datar, Paris.

Csapó, T., \& Balogh, A. (Eds.) (2012). Development of the Settlement Network in Central European Countries. Past, Present, Future. Spinger-Verlag, Berlin Heidelberg. http://dx.doi.org/10.1007/978-3-642-20314-5

Csomós, Gy. (2011). A közép-európai régió nagyvárosainak gazdaságirányító szerepe. Tér és Társadalom, (25.), 3., 129-140.

EC, (2008). Regions 2020. An Assessment of Future Challenges for EU Regions. European Commission, Brussels.

Ehrlich, É., Révész, G., \& Tamási, P. (1994). Kelet-Közép-Európa honnan-hová? Akadémiai Kiadó, Budapest.

Enyedi, Gy. (1996). Regionális folyamatok Magyarországon az átmenet idöszakában. Ember, település, régió. Hilscher Rezső Szociálpolitikai Egyesület, Budapest.

Enyedi, Gy. (2010). Városok a közép-európai átmenetben. In. Barta, Gy., Beluszky, P., Földi, Zs., \& Kovács, K. (eds.) A területi kutatások csomópontjai. MTA RKK, Pécs. 223-244.

Fábián, A. (2011). Alkalmazott strukturális politikák Közép-Európában. Nyugat-magyarországi Egyetem Kiadó, Sopron.

Gorzelak, G. (1996). The regional Dimension of Transformation in Central Europe. Regional Studies Association, London.

Horváth, Gy. (2000). Decentralizáció és a régió - kelet-közép-európai nézőpontok. In. Horváth, Gy., \& Rechnitzer, J. (eds.) Magyarország területi szerkezete és folyamatai az ezredfordulón. MTA RKK, Pécs. 60-73. o.

Horváth, Gy., Hajdú Z. (eds.) (2010). Regionális átalakulási folyamatok a Nyugat-Balkán országaiban. MTA RKK, Pécs.

Illés, I. (2002). Közép- és Délkelet-Európa az ezredfordulón. Átalakulás, integráció, régiók. Dialóg Campus Kiadó, Budapest-Pécs. 
Krugman, P. (1994). Competitiveness: A dangerous obsession. Foreign Affairs, 2. http://dx.doi.org/10.2307/20045917

Krugman, P. (1999). The role of geography in development. International Regional Science Review, 2, 142-161. http://dx.doi.org/10.1177/016001799761012307

Krugman, P. (1998). Space: The Final Frontier. Journal of Economic Perspectives, 2. 161-175. http://dx.doi.org/10.1257/jep.12.2.161

Kunzmann, K. R. (1992). Zur Entwicklung der Stadtsysteme in Europa. In. Stiglbauer, K. (ed.) Mitteilungen der Österreichischen geografischen Gesellschaft. Band 134. Wien. 25-50.

Kuttor, D. (2012). Kelet-Közép-Európa változó gazdasági térszerkezetének modellezése. Miskolci Egyetemi Kiadó, Miskolc.

Lengyel, I. (2000). A regionális versenyképességröl. Közgazdasági Szemle. 12. 962-987.

Lengyel, I. (2003). Verseny és területi fejlödés. JATEPress, Szeged.

Lengyel, I., \& Rechnitzer, J. (2004). Regionális gazdaságtan. Dialóg Campus Kiadó, Budapest-Pécs.

Lengyel, I. (2004). The Pyramid Model: Enhancing Regional Competitiveness in Hungary. Acta Oeconomica 3. http://dx.doi.org/10.1556/AOecon.54.2004.3.3

Lengyel, I. (2012). A kelet-közép-európai országok régiónak versenyképessége. In. Rechnitzer, J., \& Smahó, M. (eds.) Jármüipar és regionális versenyképesség. Széchenyi University Press, Györ. 191-229.

Lever, W. (1995). The European Regional Dimension. In. Lever, W., Bailly, A. (eds.) The spatial impact of economic changes Europe. Vermont. 178-203.

Lux, G. (2009). Reindusztrializáció Közép-Európában. In. Fodor, I. (ed.) A régiók újraiparosítása a Dél-Dunántúl esélyei. 20-35.

Mezei, C. (2006). Helyi gazdaságfejlesztés Kelet-Közép-Európában. Tér és Társadalom, (20.), 3., 95-108.

Molnár, E. (2012). Kelet-Közép-Európa az autóipar nemzetközi munkamegosztásában. Tér és Társadalom (26.), 1., $123-137$.

OECD, (2011). Local Economic and Employment Development (LEED). OECD Publishing, Paris.

Rechnitzer, J. (1998). A területi stratégiák. Dialóg-Campus Könyvkiadó, Budapest-Pécs.

Rechnitzer, J., \& Smahó, M. (2011). Területi politika. Akadémiai Kiadó, Budapest.

Rechnitzer, J., \& Smahó, M. (2012). A jármü- és autóipar hatása a kelet-közép-európai térség versenyképességére. Magyar Tudomány, 7., 38-48. o.

Szabó, L. (1998). A gazdasági növekedés elemzési tapasztalatai. A gazdaságelemzés módszerei 1. KSH Ecostat, Budapest.

Szabó, P. (2009). Európa térszerkezete különbözö szemléletek tükrében. Földrajzi Közlemények, 2., 121-134.

Szabó, P. (2012). A fejlettség térszerkezetének elméleti és módszertani kérdései, kartografikus megjelenése és területpolitikai hasznositása. ELTE, Budapest.

Szücs, J., \& Hanák, P. (1986). Európa régiói a történelemben. Elöadások a Történettudományi Intézetben 3. MTA Történettudományi Intézet, Budapest.

Tagai, G. (2010). A városok szerepe a kelet-közép-európai országok térszerkezetének formálódásában. In. Barta, Gy., Beluszky, P., Földi, Zs., \& Kovács, K. (eds.) A területi kutatások csomópontjai. MTA RKK, Pécs. 244-261. 